\title{
Europeanisation in the 'Southern Periphery': Comparative Research Findings on the EU's Impact on Domestic Political Economies
}

\section{Canan Balkir , H. Tolga Bolukbasi \& Ebru Ertugal}

To cite this article: Canan Balkir , H. Tolga Bolukbasi \& Ebru Ertugal (2013) Europeanisation in the 'Southern Periphery': Comparative Research Findings on the EU's Impact on Domestic Political Economies, South European Society and Politics, 18:2, 259-280, DOI: 10.1080/13608746.2013.795043

To link to this article: https://doi.org/10.1080/13608746.2013.795043

曲 Published online: 04 Jun 2013.

Submit your article to this journal $\widetilde{ }$

Џلll Article views: 366

Citing articles: 2 View citing articles $\square$ 


\title{
Europeanisation in the 'Southern Periphery': Comparative Research Findings on the EU's Impact on Domestic Political Economies
}

\author{
Canan Balkir, H. Tolga Bolukbasi and Ebru Ertugal
}

This article presents the comparative findings of six case studies of continuity and change in Southern European political economies which make use of the Europeanisation research programme. It summarises the varied European Union (EU) level inputs, frameworks or agendas in the different policy areas that each case study focuses on. It gauges the magnitude and direction of domestic change at the level of policy and governance in each political economy. In order to show how the case studies unpack the relationship between the EU input and domestic change in public policies, the article explains how the prevalent ideas, dominant interests and structuring institutions co-determine the nature of domestic change in political economies.

Keywords: Europeanisation; Political Economy; Ideas; Interests; Institutions; Southern Europe

This article presents comparative findings based on the six case studies on Greece, Italy, Malta, Portugal, Spain and Turkey included in this volume titled "Europeanisation and the Southern Periphery' in Retrospect: Another Decade of Dynamism, Asymmetry, and Fragmentation?' through an analytical framework drawn up on the basis of the research questions set out by Balkir, Bolukbasi and Ertugal (2013). Its goal is to show how the contributions in this volume aim to follow the most recent research design focusing on $f$ as represented in the equation $Y=f(X)$, where $X$ represents the EU input and $Y$ represents domestic change (Radaelli 2012). ${ }^{1}$ In focusing on $f$, contributions in this volume explore the relationship between the EU input and domestic change in different public policy and governance domains. In order to unpack the relationship between the EU input, on the one hand, and domestic change and continuity in public policies and 
governance arrangements, on the other, the contributions analyse the diverse constellations of ideas, interests and institutions characterising domestic political economies. By analytically reviewing the contributions in this volume, this article demonstrates that in order to focus on $f$ a practical research strategy is to capitalise on the three types of Europeanisation research that Radaelli (2012) elucidates by taking them as successive, iterative steps at capturing $f$.

Therefore, this article summarises, first, what the contributions locate as the relevant European Union (EU) level inputs, frameworks or agendas in the policy area they focus on $(X)$, which constitute their points of departure for further analysis. It shows how, by doing so, each of the case studies identify the potential 'adaptational pressure' stemming from the EU level. Second, it reviews the narratives presented in each case to gauge the magnitude and direction of domestic change at the level of policy and governance. Third, it shows that once these analytical stages laying the ground for the final research stage are completed, the case studies then continue with their final research stage where they focus on the constellation of ideas, interests and institutions to isolate the exclusive impact of the EU input (identified in the first stage) on domestic change (identified in the second stage).

Readers will notice that the three research stages that the contributors of this volume follow are, in fact, structured so as to answer the research questions set out in the introductory article (Balkir, Bolukbasi \& Ertugal 2013). The rest of this article is organised as follows. The following section draws on what the case studies take as 'EU input' in answering the research question 'What are the EU's key formal and informal rules, procedures, frames of reference, mechanisms and governance structures that may potentially bring about change at the domestic level?' The third section traces continuity and change in the outcome variables, i.e. specific public policies and governance arrangements in different political economies. It provides a comparative analytical summary of the contributors' responses to the questions 'How can we portray the direction, extent and dimensions of domestic change (as well as continuity) in Southern European political economies over the course of the last decade?' and, to the extent that the EU constitutes a key driver of change (which will be evaluated below), 'What are the different manifestations of Europeanisation in different public policy areas?', which a leading exponent of the Europeanisation research programme defines as 'Europeanisation as outcome' (Radaelli 2012, p. 7).

In doing so, this section relies on the categories deployed in the Europeanisation research programme for conceptualising and operationalising domestic change transformation, absorption, accommodation, inertia and retrenchment. The fourth section portrays comparatively the diverse constellations of prevalent ideas, powerful interests and structuring institutions representing different policy and governance areas across Southern European political economies. It summarises the findings in each of the case studies related to the questions 'How are the respective constellations of ideas, interests, and institutions representing these domains evolving?', 'How does the EU play a role in the evolution of these constellations over time?' and therefore 
'How can one portray the dynamics of Europeanisation' which Radaelli (2012, p. 7) calls 'Europeanisation as process'?

Based on the comparative findings obtained through these case studies, the concluding section revisits, more than a decade later, Featherstone and Kazamias' (2000) conclusions characterising the Europeanisation experience of Southern Europe with three key attributes_-'dynamism', 'asymmetry' and 'fragmentation'. It does so by reassessing the extent to which processes of Europeanisation in Southern Europe are still characterised by these attributes, through focusing on continuity and change in domestic political economies.

\section{'EU Input': EU-Level Frameworks, Regimes, Models, Policies, Rules}

The case studies in this volume focus on a small sample of policy and governance domains in domestic political economies. Even with such a limited sample, they collectively demonstrate that the EU has developed an elaborate, far-reaching catalogue of competences. As a result of successive waves of deepening, the 'EU input' has come to encompass formal and informal rules, procedures, frames of reference, mechanisms and governance structures. Such an extensive catalogue increasingly resembles those of contemporary polities with complex policy structures. In terms of their substantive scope, the sample of public policy and governance domains that are the focus of the case studies in this volume include social and employment policies (Malta, Spain and Turkey), macroeconomic policies (Italy and Portugal), financial regulation (Italy) and regulatory agencies (Greece) and their impact on domestic policies and governance structures. While the case studies take these policy areas as their main focus, they also speak to broad patterns of continuity and change in their respective domestic political economies.

In terms of social and employment policies, the 'EU input' is generally viewed as far from being strong, as the EU lacks both 'power' and 'resources' in these fields (Moreno 2013 , p. 222). In the area of social policy, the EU has remained incompetent and unable to impose any uniform solution to reforming national welfare states' (Ibid). In time, however, in the specific areas of old age pensions and employment policies, there was a process of progressive adoption of common approaches which went hand in hand with progressive harmonisation in 'peripheral' areas such as equal opportunities, health and safety regulations, and poverty and social inclusion programmes (Ibid).

In their discussions of EU employment policy, the case studies focus on the European Employment Strategy (EES). The EES represents the current consensus across the EU and is informed by a 'policy paradigm centring on competitiveness'. The Strategy rests on the principle of 'flexicurity', which serves its 'cognitive framework' and aims at 'activation of labour market outsiders' (Bolukbasi \& Ertugal 2013). It is based on the sharing of best practices and voluntary cooperation among member states to achieve common 'objectives' in relation to the labour market, such as the employment rate and the labour force participation rate. In terms of its governance 
structure, the EES relies on the 'participation of social partners in policymaking processes' and policy coordination is ensured through its 'governance mechanism'the Open Method of Coordination (OMC) — in member states and the co-drafting of the Joint Assessment Paper (JAP) in candidate countries.

The Strategy is equipped with financial instruments (the European Social Fund for member states and the Instrument for Pre-Accession for candidate countries). It operates through modernised public employment services in delivering active labour market policies (Bolukbasi \& Ertugal 2013). The case studies emphasise the 'soft law' basis of EU employment policy, which, they argue, renders the EES weak (Azzopardi 2013; Bolukbasi \& Ertugal 2013). In member states, the 'governance mechanism' of the $\mathrm{EES}$, the OMC, leaves the route to be taken in achieving common objectives open to domestic discretion. Although the EU input is relatively less forceful than in other policy areas that rely on 'hard law', the common approaches in the EES constrain the room for manoeuvre of governments in reform processes by promoting certain routes rather than others.

In terms of how EU inputs generally hinge upon EU-level ideas, the case study on Spain shows how the activation ideas stemming from the EU level (which was also propagated by the Organisation for Economic Cooperation and Development $[\mathrm{OECD}]$ ) have acted as the 'general framework of reference' and 'the institutional source of "good practice" stimulating female labour force participation in that country (Moreno 2013, p. 219). The potential impact of the EES on the candidate countries is thought to be through conditionality. Conditionality is accompanied by 'financial support' under the human resources component of the Instrument for Pre-Accession Assistance (IPA), which, as case studies show, acts as a carrot. The formulation of a JAP and the implementation process of IPA facilitate 'socialisation' and 'transnational learning' of EU's 'policy ideas' among policymakers at the domestic level. In terms of how ideas may be causally consequential, the case study on Malta shows that during the EU candidacy of Malta the European Commission's recommendations repeatedly 'resonated with the same message' as those of the EES ideas, which triggered processes of Europeanisation (Azzopardi 2013, p. 192). The case study on Turkey, however, demonstrates that the ideas stemming from the EU, such as flexicurity, can be strategically used by domestic actors who in turn only 'pick and choose' those parts of ideas that 'best suit their pre-determined preferences' (Bolukbasi \& Ertugal 2013).

In terms of macroeconomic policies, the EU's ever-evolving, increasingly elaborate macroeconomic policy framework has been shaped by the introduction of the Economic and Monetary Union (EMU) in 1999. The case study on Italy traces the EMU's history and shows how the EMU was inspired by the German macroeconomic model, which was the quintessential model of success over the 1980s on the road to Maastricht. By replicating this model, the EMU has come to institutionalise 'sound money' and 'sound public finance' as central principles governing monetary and fiscal policies (Quaglia 2013, p. 170). The Italian case study also shows that, while the EMU policy framework is most elaborate in central banking, monetary policy and exchange rate policy with direct explicit rules (e.g. central bank independence), there exist 'no 
hard EU rules on fiscal policy' (Ibid), which may be changing in response to the European sovereign debt crisis. Despite its asymmetric nature with respect to its economic and monetary pillars, the case study shows how the EU input, i.e. the EMU, has effectively constituted the broader framework within which domestic macroeconomic policies have been designed and implemented since the adoption of the euro.

Although the Italian case study emphasises that there are 'no hard EU rules' in the area of fiscal policy, the case study on Portugal shows that the main EU input in the area of fiscal policy has been confined to the specific fiscal rules associated with EMU membership. Both the fiscal convergence criteria included in the Maastricht Treaty and the Stability and Growth Pact (SGP) adopted in 1996 stipulate two concrete measures of budgetary discipline: 'a deficit-to-GDP ratio of three per cent and a debtto-GDP ratio of 60 per cent'. In particular, the SGP includes an Excessive Deficit Procedure (EDP) to sanction countries that breach budgetary discipline defined as such, rendering fiscal rules legally binding on the member states (Royo 2013, p. 200). Despite these de jure constraints, however, the fiscal rules were de facto breached several times even before the onset of the European sovereign debt crisis by small and large member states alike. The failure on the part of the Council of the EU to implement the EDP gave way to intense criticisms which in turn led to their amendment.

In the area of financial regulation, the case study on Italy, which focuses on the banking and securities sectors, traces how the EU's financial regime was modelled on the British approach to financial regulation. The British model, which was 'uploaded' to the EU, has traditionally been depicted as one based on 'market-making measures and a light touch regulatory philosophy' (Quaglia 2013, p. 170). In the area of banking, the EU regulatory framework rests on EU competition policy (encouraging privatisation of large public financial institutions), pre-EMU constraints (where the fiscal consolidation process required public revenues to be raised by selling off public banks), requirements of economic and monetary integration, including the completion of the single financial market (through unleashing regulatory competition in the financial sector across the EU), and other measures such as the Second Banking Directive issued in 1988 (introducing an 'all-purpose universal bank') and the endorsement of the Financial Services Action Plan by the EU (allowing foreign banks to penetrate the Italian market) (Quaglia 2013, p. 166). In the area of securities, which 'was the sector of most intense activity in the EU in the 2000s' (Quaglia 2013, p. 168), the EU regulatory framework rests on a 'market-making approach' that, through the 'Lamfalussy directives', privileges 'financial market integration', 'competition' and 'market efficiency' through 'opening up national markets' over 'financial stability, consumer protection and in some cases the protection of national operators' (Quaglia 2013, p. 169).

In the area of independent regulatory and oversight bodies, the case study on Greece documents that the EU input is 'quite concrete and prescriptive', effectively leaving no room for flexibility in domestic arrangements (Blavoukos, Caramanis \& Dedoulis 
2013, p. 140). The case study focuses, in particular, on a specific European Commission Recommendation issued in 2001 and the new Eighth Directive 2006/43/EC, which require member states to establish independent public oversight bodies. Hence, the case study on Greece shows how the 'EU input', which prescribes a very specific institutional template, details the procedures, format and composition of newly introduced institutions such as independent public oversight bodies. The case study, which emphasises the legally binding nature of the EU pressure in this area, discusses the ways in which there is 'a very low "goodness of fit" between EU policies and domestic practices' in the case of Greece (Blavoukos, Caramanis \& Dedoulis 2013, p. 144).

\section{Europeanisation 'Outcomes': Continuity and Change in Public Policies and Governance}

The case studies in this volume trace the direction, extent and dimensions of domestic change (as well as continuity) in Southern European political economies over the course of the 2000s. In doing so, they analyse the different Europeanisation 'outcomes' in different components or dimensions of a set of public policy areas that this volume takes as 'the domains where the effects of Europeanisation are supposed to materialise' (Radaelli 2003, p. 35). In conceptualising and operationalising domestic change (or the lack thereof) the case studies rely on the categories of transformation, absorption, accommodation, inertia and retrenchment that are widely used in the Europeanisation research programme. This section reviews the findings of the case studies by showing how Europeanisation advances in differentiated forms not only across different policy sectors but also within the distinctive components of a single policy sector.

The case study on Greece, which traces the establishment of the Greek independent oversight board for accounting and audit practices, demonstrates that, despite the forcefulness of the EU pressure in this particular area of governance, overall domestic change in Greece can be characterised as 'a mere absorption of the EU pressures, at best their accommodation' (Blavoukos, Caramanis \& Dedoulis 2013, p. 150). While the establishment of the independent Accounting and Auditing Oversight Board (ELTE) in 2003 satisfies, at least in façade, the EU prescriptions in this area, having realised formal policy and institutional adaptation, ELTE has not substantially been reformed in accordance with the Directive of 2006 as the traditional practice of political appointment of personnel continues to preclude its independence and effectiveness. The case study shows the overall limits of Europeanisation, by pointing to the Greek state's continuing practices to maintain indirect control through 'the appointment of party-associated experts who influence the operation of these bodies in accordance with the governmental agenda' (Blavoukos, Caramanis \& Dedoulis 2013 , p. 151-152). Such practices, the authors conclude, are characteristic of the Greek political system. Strikingly, they also contend that their findings on the establishment and the operation of ELTE can conveniently be generalised to the 
workings of other oversight and independent authorities in other policy areas in Greece. Moreover, the authors also expect to find parallel Europeanisation outcomes in other Southern European countries facing 'similar constraints' (Blavoukos, Caramanis \& Dedoulis 2013, p. 152).

In examining the outcomes of Europeanisation, the case study on Italy observes that there exists a differentiation with respect to the degree of Europeanisation between macroeconomic policies (as a case of 'strong' Europeanisation outcome) and financial regulation (which is an example of 'weak' Europeanisation outcome). First, in terms of the macroeconomic policies, although the Italian central bank followed the monetary policy of the Bundesbank prior to the establishment of EMU, the Italian monetary policy constitutes the 'most extreme case of transformation' as the policy capacity that had rested at the domestic level was effectively 'transferred to the EU level' with EMU (Quaglia 2013, p. 163). In parallel, the Italian exchange rate policy has undergone a 'major transformation' as 'the conduct of exchange-rate policy was transferred to the authorities of the euro area' as of 1999 (Quaglia 2013, p. 163). Fiscal policy, however, remained an exception to this rule as the changes therein amounted to accommodation where the 'adaptation of Italian fiscal policy to the requirements imposed by the EU and by EMU remained problematic', despite a 'major adjustment in the 1990s' (Quaglia 2013, p. 165). Second, in terms of financial services regulation, while in the area of banking and insurance the EU framework stumbled on 'domestic retrenchment' due to the protectionist intervention of the Governor of Banca d'Italia blocking a foreign takeover bid, this proved temporary, giving way to transformation (Quaglia 2013, p. 167). In the area of securities, the transposition of EU directives introduced a 'different set of priorities' into the Italian financial system and resulted in 'institutional adaptation' (Quaglia 2013, p. 169). The Italian case study shows that transformation occurs in cases of hard EU rules (such as treaty provisions in the case of monetary policy and exchange rate policy) or when hard EU rules prescribe certain institutional changes (such as in the case of financial regulation). Accommodation characterises the outcome when hard EU rules are accompanied by 'not so hard' EU rules (such as in the case of fiscal policy) (Quaglia 2013, p. 172). In fact, reversals of transformation take place when EU rules become less hard in time (such as in the case of the weakening of the SGP). Inertia occurs when EU rules are either 'only soft' or 'indirect' (as in the case of structural reforms) (Quaglia 2013, p. 171).

The case study on Malta shows that the overall Europeanisation outcomes in both labour market performance and labour market policy have been rather limited. The case study emphasises that there exists a wedge between the formal and informal labour markets in terms of the degree of Europeanisation. With regard to labour market performance in the formal sector, continuity in terms of 'high inactivity rates, untaxed work and resistance by employers to offer workers increased protection and benefits' renders the outcome in this area as retrenchment (Azzopardi 2013, p. 193). There was some improvement in employment and labour force participation rates during the 2000s, but this lasted only until about the onset of the Great Recession. Still, Malta continues to score the lowest levels in employment and labour force 
participation rates compared with EU averages, especially in the categories of women and older workers as well as among the youth (Azzopardi 2013). Moreover, skill shortages continue to remain a major challenge in the context of declining birth rates. With regard to labour market performance in the informal sector, the EU impact has been even less (Azzopardi 2013).

In terms of labour market policies, the EU's minimum requirements have been generally transposed into the Maltese legislative framework, albeit without having any impact on the fundamentals. While official policy documents have adopted the standard EU rhetoric on ideas about flexicurity (which is the EU's approach to labour markets), flexicurity as a 'practice' still has 'a long track to cover' (Azzopardi 2013, p. 191). Similarly, with respect to labour market performance, business establishments continue to find 'loopholes' in the implementation of EU legislation (Ibid). Thus, in the area of labour market policies, the Maltese case points to absorption of some of the non-fundamental aspects of the EU policies, rules and preferences without substantially modifying the core domestic practices, policies, rules or preferences.

The case study on Portugal centres on fiscal policies and performance as outcomes of Europeanisation. The forcefulness of the EU pressures stemming from EMU membership has not been sufficient in itself to lead to any transformative change in either fiscal policies or fiscal performance in Portugal. In terms of fiscal policies, the SGP has been 'insufficient to force the necessary policy reforms that would have addressed Portugal's history of fiscal mismanagement' (Royo 2013, p. 201). Thus, limited domestic change in fiscal policy explicitly 'demonstrates the limits of external pressure and the ability of the acquis communautaire to force change' (Royo 2013, p. 208). Whereas EMU pressures alone have been insufficient in bringing about reform due to the 'sheltered environment' (i.e. low interest rates and low inflation) created by the EMU, it is only with the onset of the global financial crisis since 2008 that Portugal has been under severe pressure for fiscal reform. The crisis forced the government to implement tough austerity measures. In 2011 the government promised 'the biggest cuts in government spending for more than 50 years' and introduced the 'harshest budget in living memory' (Royo 2013, p. 207). Thus, only with the recent crisis does Portugal seem to have adopted the 'sound public policy paradigm' (Royo 2013, p. 210).

In terms of fiscal performance, Portuguese fiscal balances continued to be represented by fiscal profligacy throughout the 2000s and breached the SGP's fiscal deficit rules. The author argues that this explains the country's poor economic performance during the same decade. Therefore, the change in Portuguese fiscal policy (and by implication performance) throughout the 2000s can be characterised as accommodation, as a result of the adaptation of existing domestic practices and policies to those of the EU through 'cosmetic' changes, largely maintaining the status quo without having gone through a change in their essential features (Royo 2013, p. 207).

The case study on Spain explains the changes in Spanish social and employment policies by analysing the surprising 'quantum leap' in the participation of women in 
formal labour markets, which amounts to a 'great transformation in Spanish society during 2000-10' (Moreno 2013, p. 219). Such an increase in female labour force participation is 'the most important factor' in accounting for continuity and change, not only in all areas of welfare in Spain but also across the Spanish political economy during the 2000s (Moreno 2013, p. 222). As a result of such change, Moreno observes, the Spanish welfare state during the 2000s was characterised by overall 'expansion and innovation' until the onset of the Great Recession (Moreno 2013, p. 229).

In terms of changes in Spanish social and employment policy regime, Moreno summarises the changes in the two key policy areas that have undergone transformation. The first is in labour market policies where new employment laws, including the law on positive discrimination for female employment, have been shaped by the National Action Plans for Employment and National Reform Programmes in response to the EES. A second policy area that has undergone a high degree of change is social services and care through the universalisation of long-term care, measures aiming to accomplish gender equality in the public sector, regional preschool programmes, and other legislation on conciliation and equality. The changes in other policy areas, such as education, health and income transfers, are characterised by accommodation, EU inputs being incorporated into the Spanish welfare regime, albeit with modifications in their essential features. What determines the magnitude and direction of change (i.e. transformation in some areas versus accommodation in others) in the case of Spain, the author concludes, is the extent to which the policy area in question is directly linked with rising female labour force participation.

The case study on Turkey explicitly addresses the variation with respect to the magnitude and direction of change across different components of national employment policy. In terms of the principles of employment policy, the case study focuses on four components: first, changes in Turkish labour law towards more labour market flexibility amount to a transformation, whose applicability, however, is limited to less than half of the Turkish labour force. Second, the somewhat unsystematic deployment of active labour market policies is characterised by accommodation as these policies have recently entered the official programming documents. This became possible with the restructuring of the Turkish Employment Agency (Türkiye İs Kurumu-işKUR). Third, the introduction of lifelong learning systems into the Turkish education system amounts to absorption, where EU policies and practices gradually infiltrate without substantially enhancing the policymaking and implementation capacity of the institutions overseeing these policies. Finally, although the social security system has undergone some changes, these can be characterised only as absorption, as they fail to modify the existing path-dependent domestic policies and are carried out largely independent of the EU.

In addition to the principles of employment policy, the case study reviews the changes in the objectives of employment policy and shows that the preparations for launching a national employment strategy can be viewed as accommodation to the EU's requirements in policy programming. Moreover, with respect to the procedures in governance and policymaking, improvements in the participation of social partners 
in tripartite mechanisms can only be categorised as absorption, as their ability to influence decisions remains severely restricted. In terms of instruments, increases in financial allocations for active labour market measures as a result of EU accession and İŞKUR's expanded capacity (on the road to a modernised public employment service) to deliver these measures can be categorised as accommodation.

\section{Ideas, Interests and Institutions in 'Processes' of Europeanisation}

The case studies in this volume aim to show how $X$ (EU input in the relevant policy area) and $Y$ (the magnitude and direction of domestic change) are related in a given political economy. As explained in the introductory article to this volume (Balkir, Bolukbasi \& Ertugal 2013), by focusing on the relationship $f$ the case studies aim to go beyond following a bottom-up research design. Such a research design helps contributors isolate any extraneous variable that may potentially affect the magnitude and direction of domestic change. In order to unpack the causal processes of Europeanisation in Southern European political economies, the case studies analyse the evolution of distinct configurations of prevalent ideas, powerful interests and structuring institutions representing different policy and governance areas. While the case studies aim to show how the co-dependency among ideas, interests and institutions explain domestic change as well as continuity, this section provides prominent examples of each of these that features in these narratives.

\section{Prevalent Ideas}

The case studies in this volume have conceptualised ideas as roadmaps, strategic weapons in the battle for control, and larger frames of reference. As Balkir, Bolukbasi and Ertugal (2013) (based on Schmidt 2008) explain, these ideas can be conceptualised at three different levels ranging from the more specific policy level to the more general philosophical level: policy ideas, programmatic ideas and worldviews.

At the most specific level, the case studies show the centrality of several specific 'policy ideas' or 'policy solutions' that all Southern European policymakers refer to. In the area of labour market and employment policies, policymakers, across the board, emphasised key EU 'policy ideas' of 'labour activation' and 'flexicurity'. The case study on Spain elucidates how these policy ideas are equipped with their distinct 'concepts, methodologies and indicators' (Moreno 2013, p. 229). The case study on Malta shows how these policy ideas have penetrated into the official rhetoric and discourse at the domestic level (Azzopardi 2013). The case study on Turkey demonstrates examples of how the idea of 'flexibility', under false pretences of 'flexicurity', was strategically deployed by policymakers to pursue the policy goals of enhancing 'international competitiveness' as well as legitimising 'economic liberalisation' (Bolukbasi \& Ertugal 2013 , p. 248). In the area of macroeconomic policies, the case study on Portugal depicts how the 'policy idea' of 'fiscal consolidation', which has taken root in the EU, never took hold in the Portuguese political economy over the course of the 
2000s, although this seems to be changing due to the recent global financial crisis (Royo 2013, p. 207)

At a more general level, Southern European case studies point to examples of 'programmatic ideas', 'policy paradigms' and 'frames of reference' that embed more specific policy ideas. The case study on Spain shows that the policy idea of labour activation is embedded in a larger, more general policy paradigm of 'neo-liberalism' (Moreno 2013). In parallel, the case study on Turkey demonstrates that in recent decades there has been a change in thinking on economic policymaking away from the once-dominant 'demand-side' 'Keynesian policy paradigm' towards another paradigm that emphasises the 'supply-side' (Bolukbasi \& Ertugal 2013, p. 248). Likewise, the case studies on Portugal and Italy emphasise the ascendance of the programmatic idea of the 'sound public policy paradigm' at the level of the EU. The case study on Italy, for example, demonstrates that the Italian elite used a set of 'programmatic' 'causal ideas' such as the 'stability-oriented paradigm' in legitimising reforms (Quaglia 2013, p. 171). The case study on Portugal shows, however, that this policy paradigm was never dominant in Portugal and that 'no major group or political party' lent support to it (Royo 2013, p. 210).

The Southern European case studies also provide examples of how more general, philosophical-level 'worldviews' generally underlie the more specific policy and programmatic ideas. The case study on Spain provides an example of how the changes in the Spanish welfare regime, whose 'traditional historical structure' was 'alien to [labour activation] concepts', can be represented by a new 'system of belief' (Moreno 2013 , p. 227). In Greece, the general worldviews concerning the role of the state in public policymaking shaped the fate of the newly established regulatory institutions (Blavoukos, Caramanis \& Dedoulis 2013). In Malta, societal ideas with regard to, for example, the role of women in working life hindered domestic change (Azzopardi 2013).

The case studies also show how different types of ideas (cognitive versus normative) operate in domestic political economies. They provide many examples of cognitive, causal ideas. By providing a 'new interpretive framework' defining policy problems, as well as methods with which to solve them, and around which an 'epistemic consensus' among academics and policymakers emerged, labour activation constituted a key causal idea in Spain (Moreno 2013, p. 227). The policy idea of 'flexicurity', which is used as a 'cognitive' map in Turkey, seems to have taken on a life of its own; it features as the standard referentielle in the 'everyday common policy discourse' of policymakers in the area of employment policy (Bolukbasi \& Ertugal 2013, p. 249). In Greece, politicians rediscovered 'efficiency' as a 'primary policy goal' and realised the 'strategic importance' of 'policy credibility' rendered by independent agencies (Blavoukos, Caramanis \& Dedoulis 2013, p. 140). These cognitive ideas were used by politicians, who were increasingly willing to delegate their power to technocratic bodies, to deflect blame for unpalatable reforms.

The case studies also point to the currency of normative ideas emphasising the appropriateness of policies and providing legitimacy to them by attaching values to 
political action. In Spain, the idea of labour activation provides a 'normative view' among academics and policymakers (Moreno 2013, p. 228). In parallel, in Turkey, the policy idea of 'flexicurity' is strategically used as a 'normative policy idea' as 'the only means' for fighting unemployment (Bolukbasi \& Ertugal 2013, p. 247). In Italy, policymakers have relied on 'normative ideas' such as 'visions of European political order' in seeking legitimacy (Quaglia 2013, p. 161). In Greece, in engineering a cosmetic change in the area of independent regulatory bodies, policymakers used normative ideas imported from the EU centring on the desirability of technocratic empowerment and policy expertise in policymaking at the expense of state control of such processes (Blavoukos, Caramanis \& Dedoulis 2013). In Portugal, the normative ideas that circulated widely in Brussels of the 'need to hold firm in the application of restrictive fiscal policies' and the 'achievement of budgetary surpluses' could not be transplanted into the Portuguese policymaking apparatus (Royo 2013, p. 211).

\section{Powerful Interests}

The case studies examined the preferences and strategies of dominant actor coalitions whose interests lay either in bringing about reform or in resisting it. The coalitions that feature in episodes of reform are composed of the government (especially in 'simple polities' like Turkey where governing activities are traditionally carried out through the executive), organised functional interests (employers' associations representing big and small and medium-size enterprises and trade unions and their confederations), different political parties (representing different or similar ideological positions in government or in opposition), diverse interests within public bureaucracies (characterised by clashing esprit de corps in different public institutions such as the treasury and the central bank) and epistemic communities (equipped with technocratic know-how).

The pro-reform coalitions in Southern Europe generally include ruling parties in government, employers' associations, epistemic communities and bureaucratic organisations. First, in Greece, the executive (the government in power) and prominent politicians of the ruling party constitute the most powerful interests given the institutional characteristics of the Greek political system (Blavoukos, Caramanis \& Dedoulis 2013). In parallel, the case study on Turkey identifies the government as 'the most powerful actor that is likely to bring about policy reform', not only in employment policy, but also in all public policy domains. The government features as the protagonist in virtually every account of domestic reform, which is a characteristic feature of 'simple polities' (see below) (Bolukbasi \& Ertugal 2013, p. 247).

Second, in addition to the government and ruling parties and their stronghold constituencies, the Italian case shows that bureaucratic actors, too, have led proreform coalitions. During the 1990s and 2000s, the Italian political economy was dominated by a 'macroeconomic adjustment coalition' supporting Italy's membership in the EMU (Quaglia 2013, p. 171). This coalition, members of which were 'at the 
interface between Italy and the EU', was composed of policymakers at the Bank of Italy and the Treasury (Quaglia 2013, p. 171). In particular, in the area of monetary policy, 'policy entrepreneurs' whose hands were strengthened by the Maastricht strictures were successful in bringing about reform, especially until EMU membership was achieved (Quaglia 2013). In Portugal, it is only since 2008, when the country has been faced with the risk of default, that the Bank of Portugal and the Ministry of Finance, traditionally ardent supporters of sound fiscal policies, have been influential in the design of fiscal policies (Royo 2013).

Third, interest groups based on functional representation, especially business interests, join pro-reform coalitions. In Italy, for example in the area of fiscal policy, the Italian industry represented by Confidustria joined the Bank of Italy and led a 'weak constituency that had a stake in budgetary rectitude' (Quaglia 2013, p. 165). In the area of financial regulation, 'an outward-oriented coalition' of 'large financial groups', which stood to gain from further financial integration and opening up of national financial systems, supported domestic change (Quaglia 2013, p. 171). Likewise, in Turkey, the government's preferences towards reform in the direction of increased labour market flexibility are shaped by strong domestic constituencies, composed of small and medium-size enterprises alongside traditionally strong big business (Bolukbasi \& Ertugal 2013). Accordingly, there has emerged a 'convergence of preference' between the government and the employers on emphasising exclusively the flexibility dimension in flexicurity (Bolukbasi \& Ertugal 2013, p. 250).

Fourth, the 2000s also witnessed epistemic communities composed of thinktanks and professional groups equipping pro-reform coalitions with 'scientific' rationales. In Spain, for example, an informal network of professional economists, G-100, advocated the flexibilisation of Spanish labour markets. The claims by this group were covered heavily by the media, which were in favour of introducing increased levels of flexibility into labour markets. Even after the onset of the most recent economic crisis, this influential network of economists continued to advocate the ongoing process of labour market deregulation and flexibilisation (Moreno 2013). In Malta, despite some resistance to reforms, the participation of social and economic actors, including 'employers, unions, local councils, women's organisations, the self-employed, consultancies', in EU-funded projects related to the labour market led them to advocate labour market reforms (Azzopardi 2013, p. 190).

In cases where public policy reforms have been successfully introduced, the dominant actors have relied on several strategies including 'usages' of the EU. In Spain, the strategies that allowed Spanish policymakers to carry out their reform initiatives in the direction of labour activation in particular and neoliberalism in general included 'blame avoidance devices', 'credit-claiming practices', 'emulation' and 'policy learning. In doing this, policymakers have extensively used the EU strategically in order not only to 'legitimate their positions and claims' but also to 'create hegemonic or influential positions in political debates' (Moreno 2013, p. 230). Similarly, when the Greek government intended to fix its 'tarnished image' and restore 'public confidence in the 
stock exchange' following the 1999 Athens Stock Exchange crisis, politicians instrumentally used EU pressures 'to legitimise government action' in creating ELTE. In doing so, however, they have not given up control of the policymaking process (Blavoukos, Caramanis \& Dedoulis 2013, p. 150). In parallel, Maltese policymakers have used the EU to justify and legitimise reforms otherwise unpalatable. Reform has been a treacherous enterprise, employers in particular opposing any change unless they were convinced that it stemmed from the EU. The case study also shows that the financial incentives provided by the EU have 'infiltrated material interests' and the government has coopted certain social and economic actors who have benefited from these funds (Azzopardi 2013, p. 190).

In cases where reforms stalled, resistance came from a diverse set of interests including government actors, segments of the business community, trade unions, political parties and epistemic communities. In Greece, the nature of institutional change in response to EU pressures has been rendered 'shallow and a mere façade' by the government actors themselves, who continue to maintain 'control indirectly through the appointment of party-associated experts who influence the operation of these bodies in accordance with the governmental agenda', which is a characteristic feature of the Greek political system (Blavoukos, Caramanis \& Dedoulis 2013, pp. 151, 152). In Portugal, given the absence of a strong consensus on EMU membership, policymakers did not have any incentive to enforce the new 'sound money' paradigm underlying EMU (Royo 2013).

The case studies show that anti-reform coalitions encompass diverse interests outside government. In Portugal, for example, a wide coalition composed of part of the business community, led by the Portuguese confederation of industrialists and association of bankers, as well as the Communist Party and its closer trade union confederation, openly stood against the convergence criteria in the 1990s for fear that they would undermine the Portuguese economy. Even the organised actors who were supportive of Portugal's membership in the EMU (such as the association of industrialists and a trade union) articulated serious doubts over the EMU's impact on employment and growth. Moreover, 'entrenched interest groups' composed of civil servants, unions, and professional groups (such as teachers' unions) 'were able to exercise effective veto power over any attempt to impose fiscal discipline' (Royo 2013, p. 211). In Italy, a group of 'inward-oriented', 'less competitive' financial institutions (with the support of the Bank of Italy under Antonio Fazio between 1993 and 2005) were powerful enough to have initially acted as a veto point in processes of financial market integration (Quaglia 2013, p. 171). In Malta, both employers and trade unions have resisted reforms towards flexicurity. Employers have been against these reforms, due to the perceived harm to their interests emanating from the security component of flexicurity. Unions have remained cautious in their approach too, as they have seen that the more the labour market is regulated, the less is their power in collective bargaining schemes (Azzopardi 2013). 


\section{Structuring Institutions}

The case studies identify different types of institutions that are examples of conventional systems of formal and informal rules that may constrain or enable the behaviour of actors. By representing 'the political dimensions of economic management' (Hall 1986, p. 19), these institutions structure social interactions through allocating power among different actors in a given political economy. As they also structure policymaking, institutions also shape the procedures of how decisions are adopted in a given public policy domain. The institutions that feature in the case studies concern the type of political systems, the nature of bureaucratic traditions with different forms and levels of politicisation, the variety of capitalism (with its distinct production regime, welfare state regime, industrial relations regime, corporate governance and financial system), the nature of territorial governance, the level of political instability and the level of control of the executive over the budget.

First, in terms of the type of political systems in Southern European countries, the majoritarian character of the Greek political system renders any reform attempt to establish independent regulatory agencies unlikely, as the state maintains its control through political appointments of their staff (Blavoukos, Caramanis \& Dedoulis 2013). In Turkey, the political system may be characterised as a 'simple polity' where the government enjoys ultimate power and authority in virtually all public policy domains. This means that, especially in the absence of strong veto players (which generally is the case), 'the direction and extent of domestic change become largely a function of government preferences' (Bolukbasi \& Ertugal 2013, p. 247).

Second, the nature of bureaucratic traditions with different manifestations of politicisation structure political economic outcomes too. In Turkey, for example, the hierarchical and centralised bureaucratic tradition magnifies the power and authority of the ruling political party in a highly skewed political system. When the top echelons of the bureaucracy are increasingly politicised, as was the case over the decade following the elections of 2002, such a tradition leads to a swift process of designing and implementing public policies (Bolukbasi \& Ertugal 2013). While politicisation of the bureaucracy helps explain public policy reform in Turkey, it is a source of inertia in Greece. The case study on Greece shows that the establishment of independent regulatory agencies was impossible given the 'long-established, often institutionalised' bureaucratic tradition of 'extended politicisation' (Blavoukos, Caramanis \& Dedoulis 2013, p. 140). This is a case where only cosmetic changes could be introduced, since policymakers did not wish to relinquish their political leverage on regulatory institutions.

Third, the Southern European variety of capitalism has been variously characterised as 'mixed market economies' (Molina \& Rhodes 2007), 'Mediterranean capitalism' (Amable 2003) or 'state capitalist' models (Schmidt 2003). The case studies in this special issue provide ample evidence on the institutional pillars of the Southern European political economies which largely confirms the findings of this body of literature. In terms of the production regime, the case study on Malta depicts the 
Maltese traditional production units as generally composed of 'small, mainly family owned and family run businesses', which in part explains absence of policy reform in the area of labour market policy (Azzopardi 2013, p. 192). In terms of the welfare state regime, the case study on Spain emphasises the hybrid nature of the Spanish welfare regime, composed of Bismarckian social insurance and Beveridgean tax-financed pillars. The case study shows that, as an overarching institution, the Bismarckian pillar continued to play a 'decisive institutional role' in reform processes during the 2000s in refracting the effects of rising female labour force participation (Moreno 2013, p. 228).

In terms of the industrial relations regime, the case studies on Turkey and Malta exemplify typical Southern European 'adversarial industrial relations' overwhelmed by a state playing a paternalistic role. This regime 'amplifies employers' interests' and undermines the 'positive' and 'negative veto powers' of trade unions (Bolukbasi \& Ertugal 2013, p. 248; Azzopardi 2013). The nature of the industrial relations regime, however, produced contrasting outcomes in Turkey and Malta. In Turkey, given the institutional nature of this regime, the original EU idea of flexicurity was translated into policy as flexibility only (Bolukbasi \& Ertugal 2013). In Malta, the poor record of social dialogue at the national level led to limited change with respect to labour market policy (Azzopardi 2013). Interestingly, the case study on Spain emphasises the significance of 'consensual politics' in the area of industrial relations. Although social dialogue has enabled reform since the mid-1970s, it has 'come under strain during 2000-10' given the emphasis on the 'flexibilisation of industrial relations' in political debates (Moreno 2013, p. 229).

In terms of corporate governance and the financial system, the case study on Italy shows that the Italian political economy of the 1990s was a typical representative of the Southern European variety of capitalism with an inefficient, 'dysfunctional' state with 'chronic problems with unsustainable fiscal policy' in the macroeconomic realm (Quaglia 2013, pp. 162, 173). In terms of corporate governance, the Italian model has traditionally been characterised by a 'family-type of capitalism created by an underdeveloped capital market' and an 'outdated', 'fragile national regulatory framework' (Quaglia 2013, p. XX). The financial regime, which was under the influence of the 'market-shaping approach' of the Italian state, used to be mainly 'bank oriented' with an underdeveloped securities market (Quaglia 2013, p. 169). Large state-owned banks, which restricted competition, dominated the traditional and highly segmented banking sector. Against this institutional background, the Italian political economy went institutional change over the course of the 1990s and 2000s, the macroeconomic and financial pillars of the domestic political economy converging 'towards an EU model largely informed by a (German-inspired) stability-oriented approach to macroeconomic policies, and (Anglo-Saxon-inspired) market-friendly regulation in financial services' (Quaglia 2013, p. 173).

Fourth, in terms of the nature of territorial governance, the case study on Spain shows that the process of constitutional decentralisation enabled 'policy innovation by meso-governments' whereby different subnational government levels share 'rule capacity' (Moreno 2013, p. 228). In this changing institutional structure, different 
regions compete in a process of 'policy equalisation as well as an incentive to "catch up" for those Spanish regions that traditionally lag behind "modernised" ones', which has speeded up change (Moreno 2013, p. 229).

Fifth, the case study on Portugal provides examples of how institutionalised forms of political instability account for domestic continuity and change. Political instability has manifested itself in a number of ways. Especially in the first half of the 2000s, the office of prime minister changed hands frequently. It was only between 2005 and 2011, 'the longest tenure' in 18 years, that the government was able to pursue a degree of fiscal consolidation (Royo 2013, p. 208). Likewise, until 2005 the Ministry of Finance had not been powerful enough to control fiscal policies with 'ministers often resigning in protest at their inability to reign over their colleagues' (Royo 2013, p. 208). Additionally, the minister of finance has had limited control over the budget, which also helps explain the absence of reform in the area of fiscal policy and governance in Portugal until the onset of the global financial crisis.

\section{Conclusions}

This article, first, summarises the varied EU-level inputs, frameworks or agendas in the different policy areas each case study focuses on. Second, it gauges the magnitude and direction of domestic change at the level of policy and governance in each political economy. Third, it explains how the prevalent ideas, dominant interests and structuring institutions affect the nature of domestic change in political economies. Based on the discussion above, this section provides a set of overall conclusions pointing to the diverse nature of the EU input, the differentiated nature of the EU's impact across different dimensions in a given policy sector and the co-dependency of ideas, interests and institutions in accounting for domestic change as well as continuity.

This volume examines processes of continuity and change in Southern European political economies during the decade following the publication of Featherstone and Kazamias (2000). Although the Great Recession started towards the end of the decade examined by the volume, the case studies mainly focus on the trajectories of Southern European countries until the early period of the crisis. Although the case studies do not exclusively focus on how the Southern European political economies are responding to the crisis, they shed empirical light on the causes of the crisis as well as on the inherited legacies that inevitably have played a role in conditioning these countries' crisis responses.

In terms of the nature of the EU's role, the case studies in this volume attest to the EU's wide-ranging inputs in diverse domains of policy and governance. The case studies demonstrate that these inputs have the potential to run deep throughout a given policy area. They range from more general and highly abstract policy and governance templates to more specific and rather concrete tools. Among the general templates are the broad approaches (e.g. the EU's 'approach to labour markets', centring on flexicurity that reconciles labour market flexibility and security; and its 
'market-making approach' in the area of financial regulation following the British model), frameworks of reference (e.g. activation of the labour force; the EMU delineating a broad macroeconomic framework for domestic policymakers; the EU's regulatory framework in financial regulation centring on EU competition policy, preEMU constraints and post-EMU requirements) and comprehensive strategies (e.g. the EES coordinating national governments' efforts to create more and better jobs).

At the same time, among the more specific tools, EU inputs may involve very specific targets (e.g. the headline goals of the EES aiming to achieve higher labour force participation rates, higher levels of educational attainment and lower school drop-out rates, and to reduce the number of people in or at risk of poverty and social exclusion) and concrete policy measures (e.g. measures such as guidelines, declarations and opinions adopted within the context of the workings of the EES and aimed at creating or maintaining employment with different time horizons, targeting all workers or tailored to specific groups; and measures and sanctions for countries breaching fiscal rules defined by the Excessive Deficit Procedure of the Maastricht Treaty which was bolstered by the SGP). With respect to their binding status, these measures may take the form of usually non-binding 'soft law' (e.g. measures associated with the EES such as guidelines, declarations and opinions; the Broad Economic Policy Guidelines aiming to coordinate macroeconomic policy associated with the workings of the EMU), which is, in principle, distinguished from legally binding 'hard law' that is the outcome of the traditional 'Community Method' (e.g. the Second Banking Directive of 1988 and the more recent 'Lamfalussy Directives' governing financial regulation; the European Commission Recommendation of 2001 and the Eighth Directive of 2006 requiring member states to establish independent public oversight bodies).

In terms of the nature of the EU's impact at the domestic level, the case studies collectively show that,despite the complex and elaborate policy and governance structure of the EU, uniformity in 'Europeanisation as outcome' across member states and candidate countries is not a foregone conclusion. In fact, the findings of the more recent waves of the Europeanisation research programme, especially when taken together with those of the literature on 'differentiated integration', suggest that there are neither substantive nor theoretical reasons to expect uniform Europeanisation outcomes across different clusters of states, whose levels and nature of integration with the EU are different, ceteris paribus. As defined in a recent research review, EU rules and policies whereby 'the territorial extension of EU membership and EU rule validity are incongruent' constitute 'cases of differentiated (or flexible) integration' (Holzinger \& Schimmelfennig 2012, p. 292). Southern Europe, as depicted by the original special issue that inspired the present volume, is composed of states that are differentiated 'according to the length of EU membership; states inside and outside the EU; the size of state; and historically competing identities and ties' (Featherstone \& Kazamias 2000, p. 2). At the same time, there is no intuitive rationale for expecting uniform outcomes across a set of policy and governance areas in a given political economy.

What is perhaps more striking in light of the evidence presented in the case studies in this volume, however, is that there is also no uniformity in Europeanisation 
outcomes across different components of a given policy and governance sector in a given political economy. The Europeanisation research programme and the 'differentiated integration' literature should take into account the fact that different components in or dimensions of a given a policy sector may become Europeanised at variable speeds. Regardless of the level at which we observe outcomes, our South European case studies show that instances of limited change (such as absorption or accommodation) occur more frequently than other categories of change, including absence of change (i.e. inertia), significant change yet in the opposite direction of EU inputs (retrenchment) and wholesale replacement of domestic practices, policies, rules, etc. (i.e. transformation) due to, or in parallel with, EU pressures.

In terms of how ideas, interests and institutions co-determine outcomes, the case studies in this volume unequivocally suggest that the ideas that played a prominent role in domestic policy change invariably had their sources in the EU. ${ }^{2}$ These case studies also suggest that these ideas themselves do not have a direct bearing on the outcome. When they have an impact, they do so only when they are mediated by the dominant interests in respective institutional contexts. Such mediation may take different forms. First, ideas may be used as strategic weapons in the battle for control. Powerful interests may embrace and instrumentally use ideas stemming from the EU. They may even go all the way to champion them in different platforms, as was the case in Spain. Alternatively, dominant actors may cherry-pick only one idea in a given package of ideas and strategically use it partially when they engineer cosmetic change, as the case studies on Greece and Turkey show. Moreover, EU ideas may be welcomed as scapegoats or garbage cans when dominant interests, as in the case of Italy, intend to deflect blame for policies otherwise unpalatable. Second, EU ideas may be resisted altogether by dominant actor coalitions whose interests, as in the cases of Portugal and Malta, would either be hampered or simply not affected by them. Third, certain ideas, which may have been resisted in the first place, may become more attractive in time and only after they are bundled together with additional incentives (such as EU financial assistance under the IPA and the European Social Fund), as in the case of Malta.

At the same time, the case studies show how path-dependent institutional structures strengthen the hands of certain actors. For example the institutional features of macropolitical systems that may be characterised as simple polities empower ruling parties, as the case studies on Greece and Turkey demonstrate. A second example is the institutional arrangements represented by certain bureaucratic traditions where politicisation, again as in the cases of Greece and Turkey, renders policy change simply a function of government interests. A third example is the legacy of adversarial industrial relations empowering dominant business actors to pursue their interest in the political realm, as in the cases of Malta, Spain (only after the onset of the Great Recession) and Turkey. A fourth example is the nature of a production regime that strengthens small and medium-size enterprises whose support leads to policy reform as in Turkey, or whose lack of support for reform prevents it coming about. A final example is a type of financial system whose traditional structure, as in the case of Italy, 
over-determines which interests matter in the game of resisting or bringing about change.

When we review the findings of this volume with respect to 'Europeanisation outcomes' and 'Europeanisation processes', we conclude that the South European experience of Europeanisation is still characterised by the three key attributes observed by Featherstone and Kazamias (2000) more than a decade ago. Dynamism continues to prevail as processes of Europeanisation remain an interactive, iterative process between actors, domestic and European or both', with contingent evolution of public policies resulting in 'uncertain', and at times 'reversible', outcomes across Southern Europe (Featherstone \& Kazamias 2000, p. 12, p. 3). Asymmetry is still the norm in Southern European political economies because unfolding Europeanisation processes are 'incremental, irregular and uneven over time and between locations, national and subnational', resulting in profound disparities not only within and without the region, but also among different policy areas and different dimensions of a given policy area (Featherstone \& Kazamias 2000, p. 11). As the case studies show, fragmentation remains a key Southern European trait as Europeanisation continues to 'create and reinforce domestic cleavages' and restructure 'the power, preferences and interests of sets of actors', setting new constraints, revising opportunities and redefining preferences and interests (Featherstone \& Kazamias 2000, p. 13).

\section{Notes}

[1] As reviewed in the introductory article of this volume by Balkir, Bolukbasi and Ertugal (2013), Radaelli (2012) differentiates between three types of Europeanisation research. The first type of Europeanisation research focuses on the EU input $(X)$ as its point of departure and in search of the 'effects of causes' adopts a top-down research design focusing on the impact of 'adaptational pressure' on domestic change $(Y)$. The second type of research starts from analysing domestic change $(Y)$ where the potential impact would take place and then in search of the 'causes of effects' adopts a bottom-up research design tracing the possible causes of domestic change, which may or may not include the EU input. The third type of research focuses on $f$ in isolating the exclusive impact of the EU input on domestic change, once the relationship between $X$ and $Y$ has been analytically unpacked.

[2] This may be an indication of the peripheral status of the South European countries within the $\mathrm{EU}$ as importers (rather than exporters) of policy ideas, policy paradigms or worldviews.

\section{References}

Amable, B. (2003) The Diversity of Modern Capitalism, Oxford University Press, Oxford.

Azzopardi, R. M. (2013) 'All hands on deck! How Europeanised is the Maltese labour market?', South European Society and Politics, vol. 18, no. 2, pp. 177-196.

Balkir, C., Bolukbasi, H. T. \& Ertugal, E. (2013) 'Europeanisation and dynamics of continuity and change in domestic political economies in the "Southern Periphery", South European Society and Politics, vol. 18, no. 2, pp. 121-137. 
Blavoukos, S., Caramanis, C. \& Dedoulis, E. (2013) 'Europeanisation, independent bodies and the empowerment of technocracy: the case of the Greek auditing oversight body', South European Society and Politics, vol. 18, no. 2, pp. 139-157.

Bolukbasi, H. T. \& Ertugal, E. (2013) 'Europeanisation of employment policy in Turkey: tracing domestic change through institutions, ideas and interests', South European Society and Politics, vol. 18 , no. 2, pp. 237-257.

Featherstone, K. \& Kazamias, G. (2000) 'Introduction: Southern Europe and the process of "Europeanization"', South European Society and Politics, vol. 5, no. 2, pp. 1-24.

Hall, P. A. (1986) Governing the Economy: The Politics of State Intervention in Britain and France, Oxford University Press, Oxford.

Holzinger, K. \& Schimmelfennig, F. (2012) 'Differentiated integration in the European Union: many concepts, sparse theory, few data', Journal of European Public Policy, vol. 19, no. 2, pp. 292-305.

Molina, O. \& Rhodes, M. (2007) 'The political economy of adjustment in mixed market economies: a study of Spain and Italy', in Beyond Varieties of Capitalism, eds B. Hancke, M. Rhodes \& M. Thatcher, Oxford University Press, Oxford, pp. 223-252.

Moreno, L. (2013) 'Spain's catching up with the EU core: the implausible quest of a "flying pig"?', South European Society and Politics, vol. 18, no. 2, pp. 217-236.

Quaglia, L. (2013) 'The Europeanisation of macroeconomic policies and financial regulation in Italy', South European Society and Politics, vol. 18, no. 2, pp. 159-176.

Radaelli, C. M. (2003) 'The Europeanisation of public policy', in The Politics of Europeanisation, eds K. Featherstone \& C. M. Radaelli, Oxford University Press, Oxford, pp. 27-56.

Radaelli, C. M. (2012) 'Europeanization: the challenge of establishing causality', in Research Design in European Studies: Establishing Causality in Europeanization, eds T. Exadaktylos \& C. M. Radaelli, Palgrave Macmillan, Basingstoke, pp. 1-16.

Royo, S. (2013) 'Portugal in the European Union: the limits of convergence', South European Society and Politics, vol. 18, no. 2, pp. 197-216.

Schmidt, V. A. (2003) 'French capitalism transformed, yet still a third variety of capitalism', Economy and Society, vol. 32, no. 4, pp. 526-554.

Schmidt, V. A. (2008) 'Discursive institutionalism: the explanatory power of ideas and discourse', Annual Review of Political Science, vol. 11, pp. 303-326.

Canan Balkir is Jean Monnet Chair in European Economic Integration and Professor of Economics in the Department of EU Studies at Dokuz Eylul University. Her current research interests include knowledge transfer in innovation networks, economics of international retirement migration, and EU-Turkey trade issues. Her publications include International Economic Integration: Theory, Policy and Practice- EU and Others (Bilgi University Publications, 2010), 'Turkey, the new destination for international retirement migration' (with B. Kirkulak) in Migration and Mobility in Europe: Trends, Patterns and Control, edited by H. Fassmann, M. Haller and D. Lane (Edward Elgar, 2009), and 'Economics and the politicisation of civil society: the Turkish-Cypriot case' (with G. Yalman) in Cyprus: A Conflict at the Crossroads, edited by N. Tocci and T. Diez (Manchester University Press, 2009).

H. Tolga Bolukbasi is Assistant Professor of Political Science at Bilkent University. His current research interests include political economy of economic policy choice, new 
institutionalisms, Europeanisation of socio-economic governance in Turkey and elite attitudes in Turkey towards EU-Turkey relations. His publications include 'Political economy' in Routledge Handbook of Modern Turkey (2012), edited by M. Heper and S. Sayari, 'Of context, interaction and temporality: historical institutionalism and Turkey's approach to the ENP and the UfM' in Comparative European Politics (2011) (with S. Ozcurumez) and 'On consensus, constraint, and choice: economic and monetary integration and Europe's welfare states' in Journal of European Public Policy (2009).

Ebru Ertugal is currently a visiting researcher at Bilkent University. She was formerly Jean Monnet Chair in European Integration Studies and assistant professor in international relations and the EU at Izmir University of Economics. Her current research interests include comparative regional policy and governance, Europeanisation of public policies and Turkey-EU relations. Her publications include 'Europeanization and institutional change: explaining regional policy reforms in Turkey' in Policy and Politics (2011), 'Europeanization and multi-level governance in Turkey' in Southeast European and Black Sea Studies (2010) and 'Dynamics of regionalisation and the impact of the EU: comparing regional reforms in Romania and Turkey' in Europe-Asia Studies (2011) (with A. M. Dobre). 